\title{
THE ANNUAL EFFECTIVE DOSE FOR SOME FOOD CROPS SAMPLES USING ALPHA TRACK DETECTOR
}

\author{
Hesham A. Yousef \\ Physics Department, Faculty of Science, Suez University, Suez, Egypt \\ Email: h_yosef2013@yahoo.com
}

\section{ABSTRACT}

Radon gas arrives the indoors from different sources and very important in human life because it is harmful on the human population. Radon concentrations were measured in some crops samples from the local market by Suez government, Egypt, using alpha track detector from the type of CR-39. The values of the annual effective dose varied from 1.94 $1.21 \mathrm{mSvy}^{-1}$. The obtained results indicate that the values of annual effective dose lower than the recommended limit of ICRP. We conclude that there is no health hazard due to radon gas, when used in eating of the food crops samples in this study. This work will help to provide an important database about the radiation hazard from food crops, which used in our houses.

\section{Keyword}

Radon, Crops, CR-39, Effective dose, Food.

\section{INTRODUCTION}

Radon is a radioactive gas comes from natural decay of uranium decay series that is found in nearly all rocks, soils, and water [1]. When radon gas is inhaled, densely ionizing alpha particles emitted by depositing decay products of radon $\left({ }^{218} \mathrm{Po}\right.$ and $\left.{ }^{214} \mathrm{Po}\right)$ can interact with biological tissue in the lungs leading to DNA damage [2]. Radon is radioactive isotopes and its half-life of 3.82 days. The subseries decays of radon decays into many short lived daughter progeny among which ${ }^{218} \mathrm{Po}$ and ${ }^{214} \mathrm{Po}$ are very high alpha emitter [3].

However, it is not the radon itself, but the alpha particles produced during the decay process and the highly radioactive daughter products that are considered as environmental health hazard. People exposed to radon have confirmed that radon in homes represents a serious health hazard. The main health risk associated with long-term, elevated exposure to radon is an increased risk of developing lung cancer, which depends on the radon concentration and exposure time [4]. When an individual spends time in an atmosphere that contains radon and its decay products. In addition, the organs, including the kidney and the bone marrow, may receive low doses [5]. If an individual drinks water in which radon is dissolved, the stomach will also be exposed [6]. There are different methods for measurement of radon gas and its decay products, which are classified according to their sampling adopted procedures. Passive technique is more suitable for the measurement of radon [7]. SSNTD's are widely used in detecting radon and considered to be most used devices for radon concentration measurements. CR-39 plastic track detector was used for the evaluation of radon concentration in different types of crops samples [8]. The radionuclides present in the environment are transferred to plant uptake from soil through the roots. When food crops are grown in the contaminated soil, the activity is shifted from the soil to the roots and then shoots. At the end, activity is transferred to the human diet [9]. The radioactive elements can be transferred into plants along with the nutrients via minerals uptake which accumulate in various parts and reach edible portions [10]. Since all crops samples contain various amounts of natural radionuclides, and those radionuclides are sources of radon, then the knowledge of the natural radioactivity of crops are important to determine population exposure to radiations [11]. Traders monopolize food and stored for a long time, this is leading to radon exhalation, which harmful to health and nutrients in Egyptian homes, which consumption every day. This work aimed to measure radon concentration in food crops samples (lentil, cumin, anise, black pepper, coriander and other crops) collected from a local market in Suez Governorate, Egypt. This data will provide an important database about the radiation hazard from crops, which used in our houses.

\section{MATERIALS AND METHODS}

Fifteen samples from food crops samples like (lentil, cumin, anise, black pepper, coriander, bean, fenugreek, fennel, cowpea, kidney beans, chickpeas, wheat flour, wheat grains, corn flour, and rice) were collected randomly from local market in Suez Governorate, Egypt and it is the most popular used in food. Radon concentration in crops samples were measured using passive technique based on CR-39 detectors. Some samples were washed, dried in air and dried in oven at $60^{\circ} \mathrm{C}$ for suitable time [12], to eliminate absorbed moisture and obtain actual dry weight. The samples were minced, crushed by using a blender (except the flour), sieved and carefully sealed for 40 days in plastic containers with diameter 8 $\mathrm{cm}$ and depth $16 \mathrm{~cm}$. Before use, containers were washed with dilute hydrochloric acid and rinsed with distilled water and assigned a code specific to each individual sample.

A piece of CR-39 detector with an area of $(1.5 \times 1.5) \mathrm{cm}^{2}$ was fixed by double stick tape at the bottom of the cover of the container. After irradiation, the detectors were collected and etched in $25 \%$ of $\mathrm{NaOH}$ solution at $70^{\circ} \mathrm{C}$ for $8 \mathrm{hr}$ [13]. After etching, the detectors were washed in distilled water and dipped in a $5 \%$ acetic acid. After this the detector washed by distilled water and dried in air. The tracks density was counted using an optical microscopic (magnification of 640x) [14] Background of CR-39 track detectors was calculated and subtracted. 
Radon concentration determines using the following relation:

Where, $\mathrm{P}$ : track density (track $\left.\mathrm{cm}^{-2}\right), \mathrm{C}_{\mathrm{Rn}}$ :radon concentration $\left(\mathrm{Bqm}^{-3}\right), \mathrm{T}$ :exposure time (day) and $\mathrm{K}$ :calibration factor of CR-39 (tracks $\mathrm{cm}^{-2} \mathrm{day}^{-1} / \mathrm{Bqm}^{-3}$ ) [15]

$\mathrm{E}=\frac{\mathrm{CV \lambda}}{\mathrm{A}\left(1-\mathrm{e}^{-\lambda \mathrm{t}}\right)}$

Where, E: surface exhalation rate $\left(\mathrm{Bqm}^{-2} \mathrm{~h}^{-1}\right), \mathrm{C}$ : concentration of radon $\left(\mathrm{Bqm}^{-3}\right), \lambda$ : decay constant of radon $\left(\mathrm{h}^{-1}\right), \mathrm{V}$ : effective volume of the container $\left(\mathrm{m}^{3}\right)$, A: sample surface area $\left(\mathrm{m}^{2}\right)$ and $t$ : irradiation time [16 - 17]. Annual effective dose rate $(H)$ in $\mathrm{mSvy}^{-1}$ due to inhalation of radon in indoor air, was calculated according to the following equation:

$\mathrm{H}\left(\mathrm{mSvy}^{-1}\right)=\mathrm{C}_{\mathrm{Rn}}$.D.F. T. R

Where, $\mathrm{F}(0.4)$ is the indoor equilibrium factor. $\mathrm{T}$ is the indoor occupancy time $(\mathrm{hr}), \mathrm{R}$ is the indoor occupancy factor $(0.8)$ and $\mathrm{D}$ is the dose conversion factor $\left(9 \times 10^{-6} \mathrm{mSv} \mathrm{h}^{-1} / \mathrm{Bqm}^{-3}\right)[18-19-20]$.

\section{RESULTS AND DISCUSSION}

The results of radon concentrations, surface exhalation rate, and annual effective dose for food crops samples were presented in Table 1. Chickpeas have the highest value of radon concentration $116.94 \mathrm{Bqm}^{-3}$, while the lowest value was found in bean $30 \mathrm{Bqm}^{-3}$. But the value radon exhalation rate ranged from 7.08 to $2.91 \mathrm{Bqm}^{-2} \mathrm{~h}^{-1}$, and the values of annual effective dose ranged from 1.94 to $1.21 \mathrm{mSvy}^{-1}$. Comparison between the values of radon concentration of the food crops samples was given by Figure 1, from this figure we find that the sample number 9 has a high value but sample number 2 has a lowest value of radon concentration. All values of radon concentration lower than the natural limits of public (400 $\mathrm{Bqm}^{-3}$ ) given by ICRP [21]. The variation of radon concentration levels for food crops refer to the wide variations in the geological formation of soil and the type of composition of soil material used during construction. Also the distribution of radionuclides in different parts of the plant depends on the chemical characteristics and several parameters of the plants and soil. Measurement of radon exhalation rate is a good indicator for the radon present in the crops samples. The data obtained show that the radon exhalation rate varies linearly with the radon concentration as shown in Figure 2, which gives a good positive correlation $\left(R^{2}=1\right)$. Figure 3 shows the correlation relation between the values of radon concentration and annual effective dose of the samples, where the correlation coefficient equal $\left(R^{2}=0.98\right)$, this is a good correlation because the values of annual effective dose depend on the values of radon concentration. The present work was compared with those listed in Table 2 are lower than those reported in the literature for different crops samples and the results of the radon concentration are in good agreement with this literature.

Table 1. The values of radon concentration, radon exhalation rate and the annual effective dose of the samples

\begin{tabular}{|c|c|c|c|c|}
\hline Sample No. & Name & $\begin{array}{c}\mathbf{C}_{\mathbf{R n}}{ }^{-3} \\
\left(\mathbf{B q m}^{-3}\right)\end{array}$ & $\begin{array}{c}\mathbf{E} \\
\left(\mathbf{B q m}^{-2} \mathbf{h}^{-1}\right)\end{array}$ & $\begin{array}{c}\mathbf{H} \\
\left(\mathbf{m S v y}^{-1}\right)\end{array}$ \\
\hline 1 & Rice & 48.05 & 2.91 & 1.21 \\
\hline 2 & Bean & 30.00 & 1.81 & 0.76 \\
\hline 3 & Lentil & 69.02 & 4.18 & 1.74 \\
\hline 4 & kidney beans & 35.97 & 2.18 & 0.91 \\
\hline 5 & Cowpea & 54.02 & 3.27 & 1.36 \\
\hline 6 & Flour & 35.97 & 2.18 & 0.91 \\
\hline 7 & Fenugreek & 45.00 & 2.72 & 1.35 \\
\hline 8 & Wheat & 76.94 & 4.66 & 1.94 \\
\hline 9 & Chickpeas & 116.94 & 7.08 & 2.95 \\
\hline 10 & Black pepper & 50.97 & 3.09 & 1.29 \\
\hline 11 & Anise & 49.03 & 2.97 & 1.24 \\
\hline 12 & Coriander & 58.05 & 3.51 & 1.46 \\
\hline 13 & Cumin & 66.94 & 4.06 & 1.69 \\
\hline 14 & Fennel & 61.94 & 3.75 & 1.56 \\
\hline 15 & Corn & 60.97 & 3.69 & 1.54 \\
\hline & & & & \\
\hline & & & & 36 \\
\hline
\end{tabular}


*The percentage of error in radon concentration equal $5 \%$

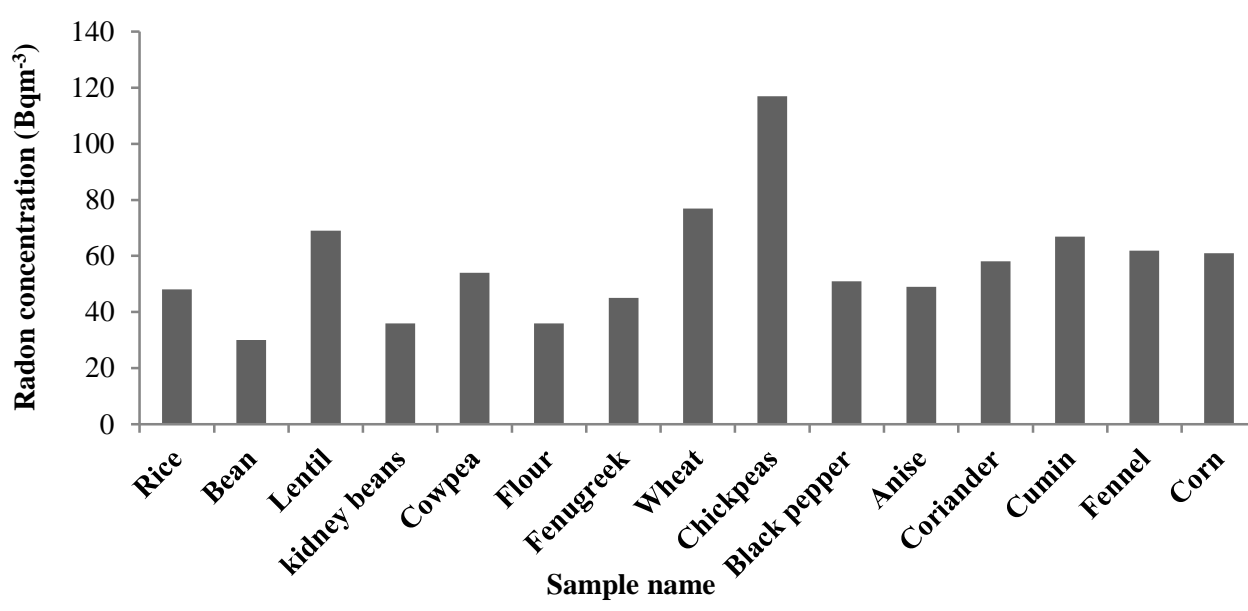

Figure 1. The comparsion between the values of radon concentration of crops samples

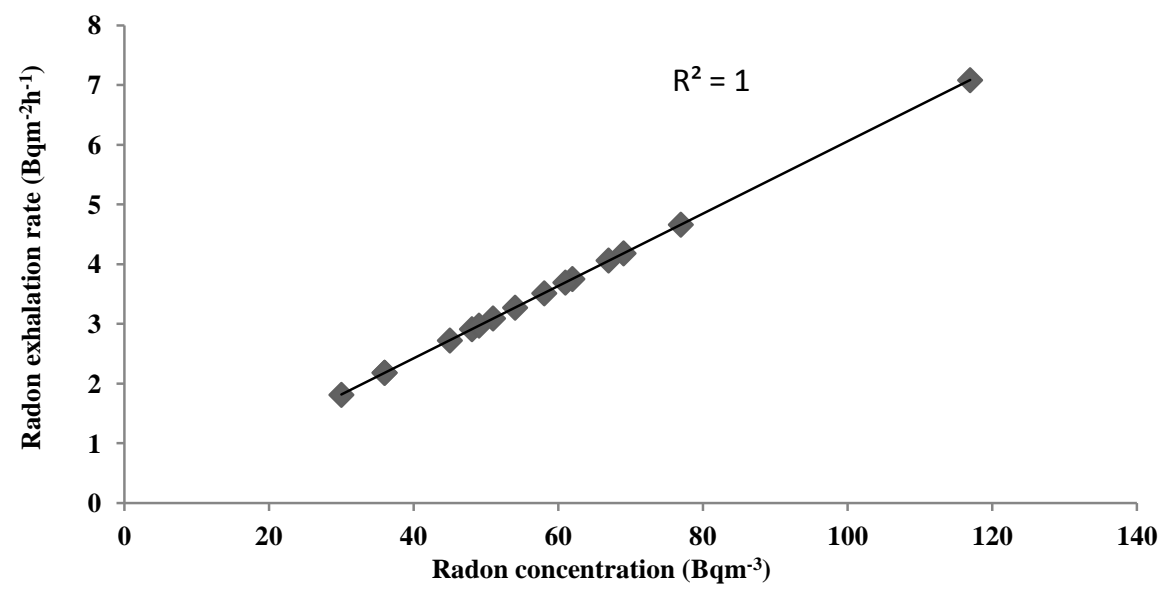

Figure 2. The correlation relation between radon concentration and exhalation rate

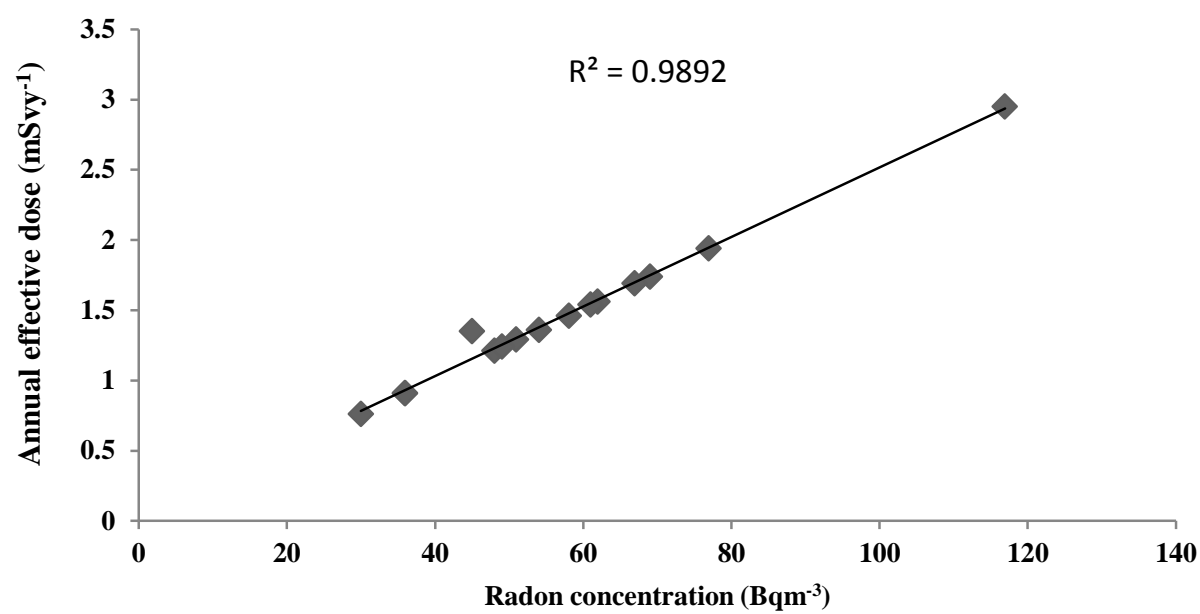

Figure 3 . The correlation relation between radon concentration and annual effective dose 
Table 2. The comparison between our results and the others

\begin{tabular}{|c|c|c|c|}
\hline Countries/Org. & Sample name & $\mathrm{C}_{\mathrm{Rn}}\left(\mathrm{Bqm}^{-3}\right)$ & References \\
\hline $\mathrm{WHO}$ & & 100 & [4] \\
\hline ICRP & & 400 & [21] \\
\hline $\begin{array}{c}\text { ICRP } \\
\text { (action level) }\end{array}$ & & $200-600$ & [22] \\
\hline Iraq & $\begin{array}{c}\text { Bean } \\
\text { Rice } \\
\text { Wheat } \\
\text { Flour } \\
\text { Kidney bean } \\
\text { Chick bean }\end{array}$ & $\begin{array}{c}24.17 \\
45.63 \\
81.24 \\
37.71 \\
137.39 \\
151.90\end{array}$ & [23] \\
\hline Egypt & $\begin{array}{c}\text { Bean } \\
\text { Rice } \\
\text { Wheat } \\
\text { Flour } \\
\text { Kidney bean } \\
\text { Chickpeas }\end{array}$ & $\begin{array}{c}30 \\
48.05 \\
76.94 \\
35.97 \\
35.97 \\
116.94\end{array}$ & The present work \\
\hline
\end{tabular}

\section{CONCLUSION}

We study radon concentration for crops in Suez Governorate in order to get on its impact on the health of the Egyptian people residing in Suez Governorate. The results showed that radon concentrations in crops samples were ranged between $(30-116.94) \mathrm{Bqm}^{-3}$. The present values of indoor radon levels found in corps samples are lower than the reference level (400 $\left.\mathrm{Bqm}^{-3}\right)$, which recommended by ICRP [21].

And lower than the action levels range (200-600) $\mathrm{Bqm}^{-3}$ ICRP [22], and also lower than level $100 \mathrm{Bqm}^{-3}$, which recommended by WHO [4]. The radon distribution in the crops samples vary from sample to another this refer to the type plant Composition. The annual effective dose ranged between (1.91 to 1.21) is found less than the lower limit of the action level (3 $\left.\mathrm{mSvy}^{-1}\right)$ recommended by ICRP [21]. And also the values of annual effective dose are lower than the worldwide average radiation dose of $2.4 \mathrm{mSvy}^{-1}$ and low the range of $(3-10) \mathrm{mSvy}^{-1}$ recommended by ICRP [21]. General public in terms of the radiological hazard, as well as the finding of this work will help in establishing a baseline of radioactivity exposure to the general public from ingestion of this type of food crops. We conclude that there is no health hazard due to radon gas, when used in eating of the crops samples in this study.

\section{REFERENCES}

1. Yablokov A.V., Nesterenko V.B. and Nesterenko A.V. Ann N.Y Acad., 2009. Chernobyl consequences of the disaster for the population and the environment. Sci.,1189.

2. UNSCEAR: Sources and Effects of lonizing Radiation. Report to the General Assembly with Scientific Annexes, United Nations Scientific Committee on the Effects of Atomic Radiation, New York (2008).

3. Abd El-Zaher M., 2011. Seasonal variation of indoor radon concentration in dwellings of Alexandria city, Egypt. J. Radiat. Prot. Dosi., 143(1), 56-62.

4. World Health Organization. WHO Handbook on Indoor Radon: A Public Health Perspective, Geneva, (2009).

5. Kendall G.M. and Smith T.J., 2005. Doses from radon and its decay products to children. J. Radiat. Prot., 25(3), 24-56.

6. Rericha V., 2006. Incidence of leukemia, lymphoma, and multiple myeloma in Czech uranium miners: a case-cohort study. Environ Health Perspect, 114(6), 818- 822.

7. Ahn G.H. and Lee J., 2005. Construction of an environmental radon monitoring system using CR-39 nuclear track detectors. Nucl. Eng. Techn. 37(4), pp. 395 - 400.

8. Shanthi G, Maniyam C. G. Raj GAG and Kumaran T.T.J, 2009. Radioactivity in food crops from high background radation area in Southwest India. Current Sci., $97(9,10)$ 1331-1335. 


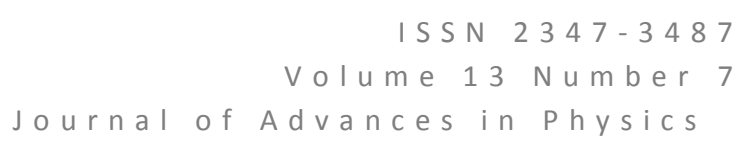

9. Robinson, D.S., 1990. Food biochemistry and nutritional value. Longman Scientific and Technical Publisher, New York, USA.

10. Abojassim, A.A., L.A. Al-Alasadi, A.R. Shitake, F.A. Al-Tememie and A.A. Husain, 2015. Assessment of annual effective dose for natural radioactivity of gamma emitters in biscuit samples in Iraq. J. Food Prot., 78, 1766-1769.

11. Nabil M, Hassan, Masahiro Hosoda, Tetsuo I., Shinji T., Masahiro F., Abdel Fattah H. and Emad KHALIL, 2009. ${ }^{222} \mathrm{Rn}$ Exhalation rate from Egyptian building materials using active and passive methods. Jpn. J. Health Phys., 44 (1), 106 -111 .

12. Santos, E.E., Lauria, D.C., Amaral, E.C.S. and Rochedo, E.R., 2002. Daily ingestion of ${ }^{232} \mathrm{Th},{ }^{238} \mathrm{U},{ }^{226} \mathrm{Ra},{ }^{228} \mathrm{Ra}$ and ${ }^{210} \mathrm{~Pb}$ in vegetables by Inhabitants of Rio de Janeiro Cit. J. Environ. Radioact., 62, 75-86.

13. Hesham A. Yousef, 2017. Effect of alpha particles on the bulk etching rate of CR-39 nuclear track detector. J. Nucl. Part., Phys., 7(2), 23-26.

14. Hesham A. Yousef, Gehad M. Saleh, A. H. El-Farrash, and A. Hamza, 2016. Radon exhalation rate for phosphate rocks samples using alpha track detectors. J. Radiat. Res. Appl. Sci., 9, 41-46.

15. Heiyam Najy Hady, Ali Abid Abojassim and Zahran Baqer Mohammed, 2016. Study of radon levels in fruits samples using LR-115 Type II detector. J. Environ. Sci. Techn., 446- 451.

16. Tufail, M., Mirza, M.S., Mahmood, A., Qureshi, A.A., Arafat, Y., Khan, H.A., 2000. Application of a closed-can technique for measuring radon exhalation from mine samples of Punjab, Pakistan. J. Environ. Radioact., 50, 267-275

17. Wafaa Arafa, 2004. Specific activity and hazards of granite samples collected from the Eastern Desert of Egypt. J. Environ. Radioact., 75, 315-327.

18. UNSCEAR: Sources and Effects of lonizing Radiation. Report to the General Assembly with Scientific Annexes, United Nations Scientific Committee on the Effects of Atomic Radiation, New York (2000).

19. Al Zabadi H., Mallah K., and Saffarini G., 2015. Indoor exposure assessment of radon in the elementary schools Palestine. Inter. J. Rad. Res., 13(3), 221-228.

20. Maria Quarto, Mariagabriell Pugliese, Giuseppe La Verde, Filomena Loffredo and Vincenzo, 2015. Radon exposure assessment and relative effective dose estimation to inhabitants of Puglia Region, South Italy. Inter. J. Res. Public Health, 12, 14948- 14957.

21. ICRP: International Commission on Radiological Protection. Statement on radon. ICRP Ref. 00/902/09. Available on: www.icrp.org/consultation_page.asp, 2009.

22. ICRP: International Commission on Radiological Protection. Oxford: Pergamum Press, ICRP Publication No. 65, 1993.

23. Ahmed A. H., and Samad A. I., 2014. Measurement of radioactivity levels in Daily intake foods of Erbil City inhabitants. J. Zankoy Sulaimania, Part A, 16(4), 111- 121.

\section{Author' biography with Photo}

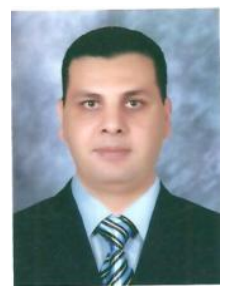

Dr. Hesham A. Yousef : (Ph.D. in Radiation and Experimental Nuclear Physics)

Physics Department - Faculty of Science -Suez University, Suez, Egypt.

h_yosef2013@yahoo.com

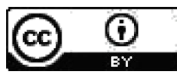

This work is licensed under a Creative Commons Attribution 4.0 International License.

DOI : 10.24297/jap.v13i7.6291 